\title{
Characteristics of carcass and of non-carcass components of lambs and hoggets fed high-concentrate corn or sorghum diets
}

\author{
Rafael Sanches Venturini ${ }^{*}$, Sérgio Carvalho², Paulo Santana Pacheco ${ }^{2}$, Ana Carolina Ribeiro \\ Sanquetta de Pellegrin ${ }^{1}$, Andressa Ana Martins ${ }^{1}$, Jusecléia Ferreira Lopes ${ }^{3}$, Anderson \\ Bortoluzzi Moro', Robson Rodrigues Simões ${ }^{1}$
}

\footnotetext{
${ }^{1}$ Universidade Federal de Santa Maria, Programa de Pós-graduação em Zootecnia, Santa Maria, RS, Brazil.

2 Universidade Federal de Santa Maria, Departamento de Zootecnia, Santa Maria, RS, Brazil.

${ }^{3}$ Universidade Federal do Rio Grande do Sul, Departamento de Zootecnia, Porto Alegre, RS, Brazil.
}

\begin{abstract}
The objective of this study was to evaluate the characteristics of carcass and non-carcass components of lambs and hoggets finished in the feedlot with high-concentrate corn or sorghum grain-based diets. Thirty-two animals were finished, comprising 16 lambs (milk teeth) and 16 hoggets (two teeth), which were distributed in a completely randomized design in a $2 \times 2$ factorial arrangement (two sheep categories $\times$ two grains). For the variables final live weight, live weight at slaughter, hot carcass weight, cold carcass weight, hot carcass yield, cold carcass yield, carcass compactness index, subjective color, loin-eye area, fasting losses, external organs, internal organs, and for the weights, in kilograms, of neck, shoulder, ribs, and leg, there was a significant difference between categories. In the variables studied for the high-concentrate diets, significant differences were found for the ribs, expressed in relative values. Lambs have much higher fasting losses, a greater proportion of internal organs, and lighter-colored meat compared with hoggets. Hot and cold carcass yields, meat subjective color, and percentage of ribs are higher in feedlot-finished lambs and hoggets fed high-concentrate sorghum-based diets compared with those fed corn-based diets.
\end{abstract}

Key Words: animal production, feedlot, grain cereal, sheep

\section{Introduction}

The sheep farming market underwent great changes in the last decades, shifting from a basically wool-exploiting activity to the meat segment. In this context, according to Carvalho and Brochier (2008), raising sheep for slaughter indicates that sheep farming can be an excellent incomegenerating alternative for farms.

However, the adopted finishing systems must meet the demands of two important links of the sheep production chain: producers and consumers. On this topic, Rodrigues et al. (2008) commented that the feedlot is an attractive feeding strategy that reduces the production cycle and provides the market with high-quality lamb.

Received: June 28, 2016

Accepted: November 21, 2016

*Corresponding author: rs_venturini@hotmail.com

http://dx.doi.org/10.1590/S1806-92902017000300011

How to cite: Venturini, R. S.; Carvalho, S.; Pacheco, P. S.; Pellegrin, A. C. R. S.; Martins, A. A.; Lopes, J. F.; Moro, A. B. and Simões, R. R. 2017. Characteristics of carcass and of non-carcass components of lambs and hoggets fed high-concentrate corn or sorghum diets. Revista Brasileira de Zootecnia 46(3):257-263.

Copyright (C) 2017 Sociedade Brasileira de Zootecnia. This is an Open Access article distributed under the terms of the Creative Commons Attribution License (http://creativecommons.org/licenses/by/4.0/), which permits unrestricted use, distribution, and reproduction in any medium, provided the original work is properly cited.
One of the many possible food alternatives to be used in a feedlot system is diets with a large participation of concentrate, which are easily manageable and provide greater operability to the system. This is because these diets carry the advantage of not requiring much time on labor with the removal and supply of roughage feeds, which reflects in lower investments in machinery and equipment. These diets also pose fewer risks, which might be triggered by possible climatic influences on the production and production of roughage feeds, thereby providing a more guaranteed planning of the activity.

The choice of feedstuffs that make up the diet is a factor of utmost importance, whereby high-energy grains such as corn (Zea mays) or sorghum (Sorghum bicolor (L.) Moench) can be used. High-starch ingredients, which are not completely fermented in the rumen and can thus reach the small intestine and be digested and absorbed as glucose, are able to provide a faster finishing period for the animals and also carcass characteristics desired by consumers.

Another important aspect is the animal category, which can influence the success of the activity, since animals of different ages have different carcass characteristics. For instance, older animals may display larger accumulation of fat, which is often not appreciated by consumers. Carvalho et al. (2016) stated that bone and muscle tissues 
have an early growth, whereas fat has a late growth in the different commercial cuts and carcass. In this regard, there is a trend for a decrease in muscle:fat ratio as animals age, which requires more in-depth knowledge of the potential of the lamb and hogget categories concerning carcass characteristics.

Just as the quantitative carcass characteristics are important parameters for sheep production, the knowledge of the non-carcass components is also relevant. With the increased competitiveness among markets, it has become necessary to exploit the byproducts generated during the production process, among which are the non-carcass components, an important alternative to increase the profitability of systems (Moreno et al., 2011).

Therefore, the objective of the present study was to evaluate the characteristics of carcass and non-carcass components of lambs and hoggets finished in the feedlot with high-concentrate corn or sorghum grain-based diets.

\section{Material and Methods}

The study was conducted in Santa Maria, RS, Brazil, from November 2013 to January 2014. The region, physiographically named Central Depression, is located at $95 \mathrm{~m}$ asl, $29^{\circ} 43^{\prime} \mathrm{S}$ latitude, and $53^{\circ} 42^{\prime} \mathrm{W}$ longitude. The climate is a Cfa (subtropical humid) type, according to the Köppen classification (Moreno, 1961). This experiment was conducted according to the ethical norms and approved by the Internal Committee of Ethics in Animal Experimentation (Case no. 059/2014).

Thirty-two castrated male Corriedale sheep, comprising 16 lambs (milk teeth) and 16 hoggets (two teeth), all originating from the same herd, and thus with similar genotype, were used in the experiment. The following treatments were tested: lambs fed a high-concentrate corn $\operatorname{diet}(\mathrm{n}=8)$; lambs fed a high-concentrate sorghum diet $(\mathrm{n}=8)$; hoggets fed a high-concentrate corn $\operatorname{diet}(\mathrm{n}=8)$; and hoggets fed a high-concentrate sorghum diet. The initial live weight and average daily weight gain were, respectively: lamb $(22.11 \pm 1.83 \mathrm{~kg} ; 0.277 \pm 0.103 \mathrm{~kg})$; hogget $(33.76 \pm 2.52 \mathrm{~kg} ; 0.109 \pm 0.068 \mathrm{~kg})$; corn $(27.77 \pm 6.88 \mathrm{~kg}$; $0.179 \pm 0.086 \mathrm{~kg})$; sorghum $(28.09 \pm 5.89 \mathrm{~kg} ; 0.206 \pm 0.150$ $\mathrm{kg}$ ). The animals were confined in fully covered individual stalls with slatted floor, measuring $2 \mathrm{~m}^{2}$ each. All stalls were provided with individual feeders and drinkers, in which the feed and water were supplied to the animals.

The diet was isoproteic for each category, composed of white oat hay (Avena sativa) and corn (Zea mays) or sorghum (Sorghum bicolor (L.) Moench) grain (Table 1). To meet the crude protein and mineral requirements, soybean meal (Glycine max) and calcitic limestone were added, respectively, according to NRC (2007), to obtain the weight gain of $200 \mathrm{~g}$ /day. Sodium bicarbonate $\left(\mathrm{NaHCO}_{3}\right)$ was also used, in the proportion of $10 \mathrm{~g} \mathrm{~kg}^{-1}$ of the total dry matter supplied, and monensin sodium (Rumensin ${ }^{\circledR}$ ), according to recommendations of the manufacturer, both to prevent

Table 1 - Proportion of ingredients and chemical composition of experimental diets

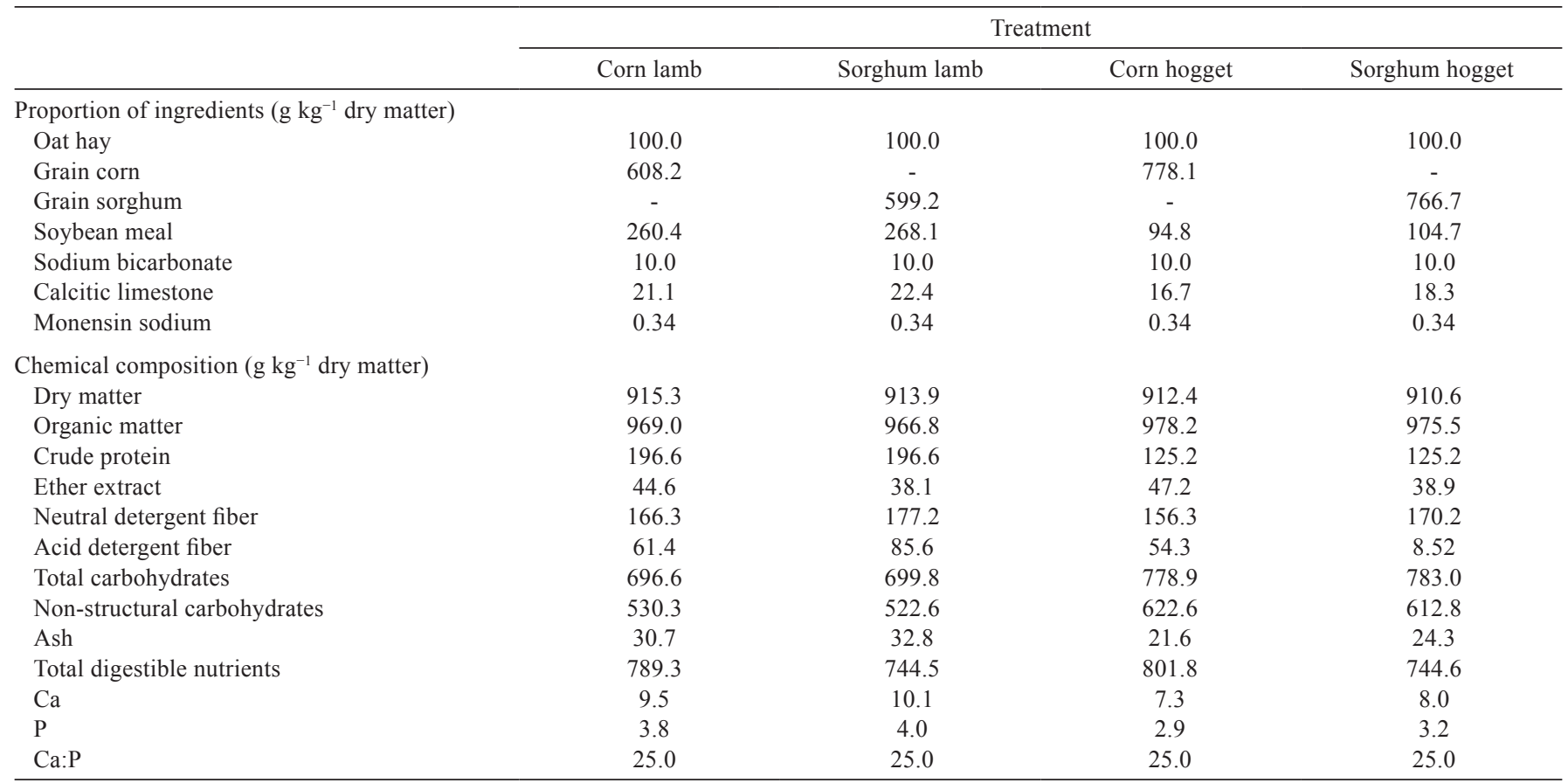


metabolic disorders. Common salt was supplied ad libitum in individual containers. The diet was supplied as a total mixture, with a roughage-to-concentrate ratio of 10:90, on a dry matter basis.

The diet was supplied to the animals ad libitum once daily, at $08.00 \mathrm{~h}$. The amount offered was adjusted according to the leftovers observed daily, which was calculated as $10 \%$ of the amount offered on the previous day to ensure maximum voluntary intake by the animals.

Upon reaching the body condition score of 3.0 (scale of 1 to 5 , with intervals of 0.25 points, in which 1 is considered excessively lean and 5 excessively fat), each lamb or hogget was weighed and the final live weight (FLW) was obtained. Next, the fasting period of solids and liquids began, lasting $14 \mathrm{~h}$. After this fasting period, the animals were weighed again to determine the live weight at slaughter (LWS).

The fasting losses (FL) were determined in kilograms (kg), by the formula FL = FLW - LWS, and also in relative values $(\mathrm{kg} / 100 \mathrm{~kg}): \mathrm{FL}=100-((\mathrm{LWS} \times 100) /$ FLW. Subsequently, the animals were stunned and then slaughtered. After skinning and evisceration, the carcass was weighed to determine the hot carcass weight (HCW). The hot carcass yield was obtained as the ratio between live weight at slaughter and hot carcass weight, as follows: $\mathrm{HCY}(\mathrm{kg} / 100 \mathrm{~kg})=(\mathrm{HCW} / \mathrm{LWS}) \times 100$. Afterwards, carcasses were taken for refrigeration in a cold room at $2{ }^{\circ} \mathrm{C}$ for $24 \mathrm{~h}$. After the chilling period, carcasses were weighed again, to determine the cold carcass weight $(\mathrm{CCW})$, the cold carcass yield $(\mathrm{CCY}(\mathrm{kg} / 100 \mathrm{~kg})=(\mathrm{CCW} / \mathrm{LWS}) \times 100)$, and the chilling loss $(\mathrm{CL}=100-((\mathrm{CCW} / \mathrm{HCW}) \times 100)$. The carcass compactness index was also calculated $(\mathrm{CCI}=$ $\mathrm{CCW}$ /carcass internal length), according to the methodology of Osório et al. (1998). Conformation (by assigning a score of 1 to 5 with 0.25 -point subdivisions, in which 1 was very poor and 5 was excellent) and fattening degree (also on a scale of 1 (too lean) to 5 (too fat)) were also determined in the carcasses, according to the adapted methodology of Osório et al. (1998).

Next, the loin-eye area was obtained by exposing the longissimus dorsi muscle after a transverse section on the carcass, between the 12th and 13th ribs, and outlining it onto tracing paper (Müller, 1980). The SITER 3.1 software model A2, described by Giotto (2001), was used to determine and record the area. In the same region, we measured the backfat thickness, using a caliper, and evaluated texture, marbling, and color subjectively (assigning a score of 1 to 5, with 0.25 -point subdivisions), following the adapted methodology of Osório et al. (1998). The right half-carcass was weighed and separated regionally into the following commercial cuts: neck, shoulder, ribs, and leg. After the separation, the different commercial cuts were weighed, and their percentage was calculated in relation to the cold carcass weight. The body condition score, conformation, fattening degree, texture, marbling, and subjective color values were obtained considering the average of the trained evaluators.

For the non-carcass components, all blood was collected and skin, paws, head, penis (termed external organs); heart, kidneys, liver, lungs, spleen, diaphragm (termed internal organs); and inguinal, renal, ruminal, and heart fats (termed internal fats) were removed. All organs were weighed separately. Rumen/reticulum, omasum, abomasum, small intestine, and large intestine (termed gastrointestinal organs) were weighed individually, together with the gastrointestinal content. Soon afterwards, different compartments were emptied and thoroughly washed; after the water was drained, they were weighed again. The content of each gastrointestinal organ was determined as the difference in weight. The sum of the contents of each organ generated the total gastrointestinal content. Next, the percentage of the different internal organs was calculated individually relative to the LWS of the animals.

The experimental design was completely randomized, in a $2 \times 2$ factorial arrangement (two sheep categories $\times$ two grains) with eight replications per treatment. The effects of sheep category, grain, and category $\times$ grain interaction were tested by variance analysis and the $\mathrm{F}$ test at $5 \%$ significance level. Means were compared by Student's t test, using the SAS statistical package (Statistical Analysis System, version 9.4). The same software was used in the study of correlation between dependent variables by calculating Pearson's correlation coefficients.

The variables body condition score, conformation, fattening degree, texture, marbling, and subjective color were considered continuous. The data were subjected to residual analysis, as follows: normality by the ShapiroWilk test $(\mathrm{P}<0.05)$ and influent observations (outlier), considering Student's $r$ criterion $(-3<$ and $>+3)$.

\section{Results and Discussion}

For all the variables analyzed in this study, no interaction was found $(\mathrm{P}>0.05)$ between animal category (lamb and hogget) and high-concentrate diet (corn or sorghum); for this reason, results were presented separately.

There was a significant difference between the categories (lamb and hogget) analyzed $(\mathrm{P}<0.05)$ for the variables FLW, LWS, FL, HCW, CCW, HCY, CCY, CCI, subjective color, and loin-eye area (LEA) (Table 2).

Concerning FLW and LWS, given that the animals had similar genotype and sex and were under the 
same management conditions (pre-experimental and experimental), the superiority $(\mathrm{P}<0.05)$ of hoggets in relation to lambs is explained by the fact that the former were 10-12 months older than the lambs and, consequently, displayed higher initial weights, which resulted in also higher final weights.

Likewise, $\mathrm{HCW}$ and $\mathrm{CCW}$ differed significantly $(\mathrm{P}<0.05)$ between the categories. These values are explained by the higher FLW and LWS of the hogget category in relation to lambs, which resulted in heavier carcasses for the older animals. In this sense, Cunha et al. (2008) reported that carcass characteristics can be influenced by some factors, the animal age being one of them. Thus, the correlation coefficients found in the present study corroborate this assertion, since the correlation existing between LWS and HCW was $0.96(\mathrm{P}<0.001)$ and between LWS and CCW was also $0.96(\mathrm{P}<0.001)$.

Although the $\mathrm{HCW}$ and $\mathrm{CCW}$ were higher in the hogget category, as explained previously, it should be noted that this category did not show desirable efficiency in meat production. This superiority of the hogget category was of approximately $25.24 \%$ and $25.13 \%$ for $\mathrm{HCW}$ and $\mathrm{CCW}$, respectively, as compared with the lamb category. This was a direct impact of the evaluated categories, in which the average weight gain of the lamb category was $0.277 \mathrm{~kg} /$ day, $154 \%$ higher than the $0.109 \mathrm{~kg} /$ day shown by the hoggets.

Fasting losses differed significantly $(\mathrm{P}<0.05)$ between the studied categories. Lambs displayed higher values for this variable than hoggets and this result can be explained by the fact that young animals typically have a higher dry matter intake than older ones when subjected to the same feeding conditions and diets. In the current study, lambs consumed $37.1 \mathrm{~g} \mathrm{~kg}^{-1}$ of their live weight (dry matter basis), whereas hoggets consumed $30.1 \mathrm{~g} \mathrm{~kg}^{-1}$ live weight, thereby corroborating the above assertion. Another aspect to be considered is that, because of their greater growth speed, lambs have a more accelerated metabolism than hoggets, which consequently leads to a higher passage rate of the feed, generating larger fasting losses. This result is supported by the negative correlation existing between LWS and FL $(r=-0.37 ; \mathrm{P}=0.0355)$, which demonstrates that the LWS increase as a consequence of the higher age of the animals in this study reduced the FL.

Hoggets showed higher values for $\mathrm{HCY}$ and $\mathrm{CCY}$ $(\mathrm{P}<0.05)$ (Table 2). However, it should be stressed that, in the present study, because of their large amount of wool at the start of the feedlot period, hoggets had to be shorn, which influenced these results. At the moment of slaughter, lambs and hoggets displayed 14.11 and $11.45 \mathrm{~kg} / 100 \mathrm{~kg}$ of live weight, respectively, for the skin variable. Vieira et al. (2010) commented that skin is one of the non-carcass components of expressive representativeness in the composition of the weight of an animal, thereby directly influencing carcass yields. This fact is interesting from the economic perspective, since one the producers is also paid according to the carcass yield. Thus, animals with large quantities of wool may have lower yields and consequently be less valued at their sale for slaughter.

The carcass compactness index differed significantly $(\mathrm{P}<0.05)$ between the categories and higher values were found in hoggets. This can be explained by the difference in carcass length, due to the different body development stages under which the animals from these categories were, at slaughter. Moreover, because of their age, hoggets had

Table 2 - Carcass characteristics of lambs and hoggets fed high-concentrate corn or sorghum diets

\begin{tabular}{|c|c|c|c|c|c|c|c|c|}
\hline & \multicolumn{2}{|c|}{ Category } & \multicolumn{2}{|c|}{ Grain } & \multicolumn{3}{|c|}{ Probability } & \multirow{2}{*}{ CV (\%) } \\
\hline & Lamb & Hogget & Corn & Sorghum & Category & Grain & Category $\times$ Grain & \\
\hline Final live weight $(\mathrm{kg})$ & 31.89 & 38.05 & 35.02 & 34.93 & $<0.0001$ & 0.9358 & 0.2330 & 8.89 \\
\hline Live weight at slaughter (kg) & 30.48 & 36.85 & 33.73 & 33.61 & $<0.0001$ & 0.9088 & 0.1846 & 8.71 \\
\hline Fasting loss $(\mathrm{kg} / 100 \mathrm{~kg})$ & 4.47 & 3.10 & 3.74 & 3.83 & 0.0046 & 0.7060 & 0.4577 & 17.28 \\
\hline Hot carcass weight (kg) & 14.34 & 17.96 & 15.94 & 16.36 & $<0.0001$ & 0.4339 & 0.5525 & 9.42 \\
\hline Cold carcass weight $(\mathrm{kg})$ & 13.85 & 17.33 & 15.41 & 15.76 & $<0.0001$ & 0.5077 & 0.5159 & 9.54 \\
\hline Hot carcass yield (kg/100 kg) & 47.06 & 48.74 & 47.21 & 48.59 & 0.0054 & 0.0197 & 0.1366 & 3.28 \\
\hline Cold carcass yield (kg/100 kg) & 45.45 & 47.02 & 45.65 & 46.82 & 0.0059 & 0.0353 & 0.1698 & 3.21 \\
\hline Chilling loss $(\mathrm{kg} / 100 \mathrm{~kg})$ & 3.51 & 3.36 & 3.38 & 3.49 & 0.2929 & 0.4150 & 0.4559 & 10.04 \\
\hline Carcass compactness index $(\mathrm{cm})$ & 0.24 & 0.28 & 0.26 & 0.26 & $<0.0001$ & 0.8026 & 0.0939 & 7.33 \\
\hline Carcass conformation (1-5) & 2.71 & 2.85 & 2.79 & 2.78 & 0.2093 & 0.8517 & 0.8737 & 10.14 \\
\hline Carcass fattening degree $(1-5)$ & 3.29 & 3.37 & 3.32 & 3.34 & 0.5479 & 0.9040 & 0.1250 & 10.89 \\
\hline Backfat thickness (mm) & 2.93 & 3.21 & 3.28 & 2.87 & 0.4749 & 0.4295 & 0.1606 & 22.95 \\
\hline Meat texture $(1-5)$ & 3.46 & 3.50 & 3.53 & 3.43 & 0.8455 & 0.5599 & 0.8455 & 12.89 \\
\hline Meat marbling (1-5) & 2.37 & 2.59 & 2.62 & 2.34 & 0.2336 & 0.1557 & 0.7654 & 10.85 \\
\hline Subjective color (1-5) & 3.12 & 3.75 & 3.21 & 3.65 & 0.0011 & 0.0185 & 0.6479 & 7.14 \\
\hline Loin-eye area $\left(\mathrm{cm}^{2}\right)$ & 12.36 & 14.43 & 13.16 & 13.62 & 0.0149 & 0.6852 & 0.3783 & 8.69 \\
\hline
\end{tabular}

$\mathrm{CV}$ - coefficient of variation.

$\mathrm{P}<0.05$. 
heavier cold carcasses than lambs, which leads to higher compactness indices. Addressing this topic, Tonetto et al. (2004) pointed out that there is a positive linear increase in CCI as the carcass weight is increased, which is corroborated by the high correlation coefficient present in the study between carcass compactness index and cold carcass weight $(\mathrm{r}=0.95 ; \mathrm{P}<0.0001)$.

For the variable subjective color, which, according to Sousa et al. (2008), has an important role in the decision of the consumer at the time of purchase, there was a significant difference $(\mathrm{P}<0.05)$ between the analyzed categories, with higher values found in hoggets. It is known that the intensity of the meat color is defined by the amount of myoglobin in it. Pinheiro et al. (2009) stated that the amount of myoglobin is related to the animal maturity and higher values are found in older animals compared with the younger.

For the variable LEA, the hoggets had higher values than lambs $(\mathrm{P}<0.05)$. Because both groups were of similar genotypes and received the same diet, this outcome may be explained by the difference in body development stage of the categories. Hoggets had heavier carcasses and, consequently, larger and better developed muscles than lambs, which reflected in the observed difference in LEA. This assertion is supported by the high correlation coefficients obtained between LEA and HCW ( $\mathrm{r}=0.62$; $\mathrm{P}<0.0001)$ and LEA and CCW $(\mathrm{r}=0.62 ; \mathrm{P}<0.001)$.

When we analyzed the results obtained from the different grains evaluated (corn or sorghum), a significant difference was noted $(\mathrm{P}<0.05)$ for $\mathrm{HCY}, \mathrm{CCY}$, and subjective color (Table 2).

As for the variables HCY and CCY, the animals fed the diet based on sorghum grain displayed superiority $(\mathrm{P}<0.05)$ in relation to those fed the corn grain-based diet. This result can be explained in part by the different energy density of the diets, which was higher in those based on corn grain (Table 1). Camilo et al. (2012) stated that the liver has a high metabolic rate and as the dietary energy is increased, this activity is intensified. As a result, the development of this organ is accelerated to meet the metabolism demands of the nutrients. According to Clementino et al. (2007), a consequence of this response is the greater development of some internal organs, which negatively influenced the carcass yields presented. In this regard, a higher proportion of liver $(\mathrm{P}<0.05)$ was observed in the animals fed the cornbased diet as compared with those consuming the sorghumbased diet (1.76 and $1.61 \%$ of the live weight, respectively), which supports the above-mentioned theory.

A significant difference $(\mathrm{P}<0.05)$ was found between the grains (corn or sorghum) for the variable subjective color in the meat of the lambs. Higher values were detected in those fed the high-concentrate diet based on sorghum grain as compared with those fed the corn diet. Bianchi and Garibotto (2002) asserted that the iron content in animal diets may influence their meat color, due to a greater myoglobin synthesis in the muscle. There is a higher concentration of this mineral in the sorghum grain as compared with the corn grain (Valadares Filho et al. 2010), which might have contributed to the obtained result.

With respect to the weights and proportions of neck, shoulder, ribs, and leg (Table 3), there was a significant difference $(\mathrm{P}<0.05)$ between the categories for all studied variables when expressed in absolute weight and only for leg when expressed in relative values. For the evaluated grains (Table 3), however, there was a significant difference $(\mathrm{P}<0.05)$ only for the variable proportion of ribs, which was higher in the sheep fed the high-concentrate corn-based diet.

The weights obtained for neck, shoulder, ribs, and leg, expressed in kilograms, differed statistically $(\mathrm{P}<0.05)$ between the categories. This result can be explained by the fact that these animals were at different ages and showed distinct slaughter weights and, consequently, cold carcass weights; the hogget category had higher values in comparison with the lambs. The correlation coefficients

Table 3 - Mean values for regional cuts, in absolute $(\mathrm{kg})$ and relative $(\mathrm{kg} / 100 \mathrm{~kg})$ values, of lambs and hoggets fed high-concentrate corn or sorghum diets

\begin{tabular}{|c|c|c|c|c|c|c|c|c|}
\hline & \multicolumn{2}{|c|}{ Category } & \multicolumn{2}{|c|}{ Grain } & \multicolumn{3}{|c|}{ Probability } & \multirow{2}{*}{ CV $(\%)$} \\
\hline & Lamb & Hogget & Corn & Sorghum & Category & Grain & Category $\times$ Grain & \\
\hline Neck (kg) & 0.570 & 0.716 & 0.617 & 0.668 & $<0.0001$ & 0.0927 & 0.6872 & 6.79 \\
\hline Shoulder (kg) & 1.383 & 1.706 & 1.535 & 1.554 & $<0.0001$ & 0.7336 & 0.6185 & 5.10 \\
\hline Ribs (kg) & 2.601 & 3.172 & 2.897 & 2.875 & $<0.0001$ & 0.8473 & 0.3811 & 4.79 \\
\hline Leg (kg) & 2.240 & 2.875 & 2.509 & 2.606 & $<0.0001$ & 0.2442 & 0.7081 & 4.67 \\
\hline Neck $(\mathrm{kg} / 100 \mathrm{~kg})$ & 8.38 & 8.60 & 8.29 & 8.67 & 0.3324 & 0.0940 & 0.4158 & 7.02 \\
\hline Shoulder $(\mathrm{kg} / 100 \mathrm{~kg})$ & 20.35 & 20.14 & 20.33 & 20.16 & 0.4926 & 0.5813 & 0.8676 & 4.28 \\
\hline Ribs (kg/100 kg) & 38.25 & 37.47 & 38.37 & 37.36 & 0.0869 & 0.0287 & 0.5310 & 3.27 \\
\hline Leg $(\mathrm{kg} / 100 \mathrm{~kg})$ & 32.99 & 33.93 & 33.13 & 33.79 & 0.0106 & 0.0634 & 0.4655 & 2.87 \\
\hline
\end{tabular}

$\mathrm{CV}$ - coefficient of variation. $\mathrm{P}<0.05$. 
Table 4 - Non-carcass components, expressed in $\mathrm{kg} / 100 \mathrm{~kg}$ of live weight, of lambs and hoggets fed high-concentrate corn or sorghum diets

\begin{tabular}{|c|c|c|c|c|c|c|c|c|}
\hline & \multicolumn{2}{|c|}{ Category } & \multicolumn{2}{|c|}{ Grain } & \multicolumn{3}{|c|}{ Probability } & \multirow{2}{*}{$\mathrm{CV}(\%)$} \\
\hline & Lamb & Hogget & Corn & Sorghum & Category & Grain & Category $\times$ Grain & \\
\hline External organs & 24.21 & 22.46 & 23.34 & 23.32 & 0.0134 & 0.9799 & 0.5909 & 8.03 \\
\hline Internal organs & 5.24 & 4.69 & 5.01 & 4.92 & 0.0004 & 0.5328 & 0.3880 & 7.82 \\
\hline Gastrointestinal organs & 5.76 & 5.97 & 6.00 & 5.73 & 0.2480 & 0.1477 & 0.4670 & 8.57 \\
\hline Gastrointestinal content & 13.01 & 13.86 & 13.76 & 13.12 & 0.2872 & 0.4166 & 0.0950 & 16.47 \\
\hline Internal fat & 2.26 & 2.52 & 2.47 & 2.30 & 0.0812 & 0.2295 & 0.1521 & 15.38 \\
\hline
\end{tabular}

$\mathrm{CV}$ - coefficient of variation.

$\mathrm{P}<0.05$.

found in the present study further justify these results, because all carcass regional cuts, expressed in absolute values, were positively and significantly correlated $(\mathrm{P}<0.05)$ with the live weight of the animals at slaughter, as follows: FLW with neck $(\mathrm{r}=0.72 ; \mathrm{P}<0.0001)$; FLW with shoulder $(\mathrm{r}=0.92 ; \mathrm{P}<0.0001)$; FLW with ribs $(\mathrm{r}=0.95 ; \mathrm{P}<0.0001)$; and FLW with leg $(\mathrm{r}=0.94 ; \mathrm{P}<0.0001)$.

For the relative values $(\mathrm{kg} / 100 \mathrm{~kg})$, a significant difference $(\mathrm{P}<0.05)$ was only noted for the leg variable, for which the hogget category had superior results than those shown by lambs. This disagrees with the expected, because the leg has an early development while the ribs have a late development (Mendonça et al., 2007); besides, there usually is a decrease in the proportion of leg and an increase in ribs as the animal grows older. However, it is worth mentioning the high negative correlation coefficient found in the present study between ribs and leg ( $\mathrm{r}=-0.66$; $\mathrm{P}<0.001$ ), which reinforces the theory that animals with a great participation of ribs lead to unsatisfactory results for the profitability of the activity, given that the leg is one of the most valued cuts from the consumer perspective.

Between the tested grains (corn or sorghum), a significant difference was only found $(\mathrm{P}<0.05)$ for percentage of ribs, which was higher in the animals consuming corn (Table 3 ). The higher energy density of the high-concentrate corn-based diet likely provided greater fat deposition in this carcass cut, which can be considered a negative aspect, since, from the commercial point of view, this is a second-class cut (Rosa et al., 2005).

As to the non-carcass components evaluated in this study, a significant difference was detected $(\mathrm{P}<0.05)$ between the categories for the variables external and internal organs (Table 4). For the other variables of category and also grain tested (corn or sorghum), no significant difference was observed $(\mathrm{P}>0.05)$ between treatments.

Regarding the external organs, lambs were superior $(\mathrm{P}<0.05)$ to hoggets; this difference may be attributed to the greater proportion of skin in the lambs. As mentioned previously, aiming at better hygiene during slaughter and more favorable environmental conditions during the confinement, the hoggets were shorn due to the large amount of wool at the beginning of the study. As a result, the proportion of skin in the lamb category was larger.

There was a significant difference $(\mathrm{P}<0.05)$ between the analyzed categories for the internal organs of the animals, whereby the lamb category displayed higher values than the hoggets. In this regard, it should be emphasized that internal organs have an earlier development (Santos-Cruz et al., 2009) and so they represent higher relative values in younger animals as compared with the older ones, in which body development was more advanced.

\section{Conclusions}

Feedlot-finished Corriedale lambs receiving highconcentrate diets based on corn or sorghum have higher fasting losses and a larger proportion of internal organs as compared with hoggets. Furthermore, hoggets have a darker meat than lambs.

Hot and cold carcass yields, meat subjective color, and percentage of ribs are higher in feedlot-finished lambs and hoggets fed high-concentrate, sorghum-based diets compared with those fed corn-based diets.

\section{Acknowledgments}

This study was financed by Coordenação de Aperfeiçoamento de Pessoal de Nível Superior (CAPES).

\section{References}

Bianchi, G. and Garibotto, G. 2002. Influencia del sexo y del largo de lactancia sobre características de crecimiento, composición de la canal y calidad de carne de cordeiros: una revisíon. Produccíon Ovina 15:71-92.

Camilo, D. A.; Pereira. E. S.; Pimentel, P. G.; Costa, M. R. G. F.; Mizubuti, I. Y. M.; Ribeiro, E. L. A.; Campos, A. C. N.; Pinto, A. P. and Moreno, G. M. B. 2012. Semina: Ciências Agrárias 33:2429-2440.

Carvalho, S. and Brochier, M. A. 2008. Composição tecidual e centesimal e teor de colesterol da carne de cordeiros terminados em confinamento com dietas contendo níveis crescentes de resíduo úmido de cervejaria. Ciência Rural 38:2023-2028. 
Carvalho, S.; Zago L. C.; Pires C. C.; Martins, A. A.; Venturini, R. S.; Lopes, J. F.; Pilecco, V. M.; Simoes, R. R.; Brutti, D. D.; Moro, A. B. 2016. Tissue composition and allometric growth of tissues from commercial cuts and carcass of Texel lambs slaughtered with different weights. Semina. Ciências Agrárias 37:2123-2132.

Clementino, R. H,; Sousa, W. H.; Medeiros, A. N.; Cunha, M. G. G.; Gonzaga Neto, S.; Carvalho, F. F. R. and Cavalcante, M. A. B. 2007. Influência dos níveis de concentrado obre os cortes comerciais, os constituintes não-carcaça e os componentes da perna de cordeiros confinados. Revista Brasileira de Zootecnia 36:681-688.

Cunha, M. G. G.; Carvalho, F. F. R.; Gonzaga Neto, S. and Cezar, M. F. 2008. Características quantitativas de carcaça de ovinos Santa Inês confinados alimentados com rações contendo diferentes níveis de caroço de algodão integral. Revista Brasileira de Zootecnia 37:1112-1120.

Giotto, E. 2001. Manual Siter 3.1. Universidade Federal de Santa Maria, Santa Maria.

Mendonça, G.; Osório, J. C. S.; Osório, M. T. M.; Wiegand, M. M.; Esteves, R. and Gonçalves, M. 2007. Crescimento e desenvolvimento de cordeiros da raça Texel nascidos em duas épocas. Revista Brasileira de Agrociência 13:361-369.

Moreno G. M. B.; Silva Sobrinho, A. G.; Leão, A. G.; Perez, H. L.; Loureiro, C. M. B.; and Pereira, G. T. 2011. Rendimento dos componentes não-carcaça de cordeiros alimentados com silagem de milho ou cana-de-açúcar e dois níveis de concentrado. Revista Brasileira de Zootecnia 40:2878-2885.

Moreno, J. A. 1961. Clima do Rio Grande do Sul. Secretaria da Agricultura, Porto Alegre.

Müller, L. 1980. Normas para avaliação de carcaças e concurso de carcaça de novilhos. Universidade Federal de Santa Maria, Santa Maria.

NRC - National Research Council. 2007. Nutrient requirements of small ruminants. National Academy Press, Washington, D.C.

Osório, J. C. S.; Osório, M. T. M. and Jardim, P. O. 1998. Métodos para avaliação da produção de carne ovina: "in vivo" na carcaça e na carne. Universidade Federal de Pelotas, Pelotas.
Pinheiro, R. S. B.; Silva Sobrinho, A. G.; De Souza, H. B. A.; Yamamoto, S. M. 2009. Qualidade de carnes provenientes de cortes da carcaça de cordeiros e de ovinos adultos. Revista Brasileira de Zootecnia 38:1790-1796.

Rodrigues, G. H.; Susin, I.; Pires, A. V.; Mendes, C. Q.; Urano, F. S. and Castillo, C. J. C. 2008. Polpa cítrica em rações para cordeiros em confinamento: características da carcaça e qualidade da carne. Revista Brasileira de Zootecnia 37:1869-1875.

Rosa, G. T.; Pires, C. C.; Silva, J. H. S. and Motta, O. S. 2005. Crescimento alométrico de osso, músculo e gordura em cortes da carcaça de cordeiros Texel segundo os métodos de alimentação e peso de abate. Ciência Rural 35:870-876.

Santos-Cruz, C. L.; Pérez, J. R. O.; Muniz, J. A.; Da Cruz, C. A. C. and Almeida, T. R. V. 2009. Desenvolvimento dos componentes do peso vivo de cordeiros Santa Inês e Bergamácia abatidos em diferentes pesos. Revista Brasileira de Zootecnia 38:923-932.

Sousa, W. H.; Cartaxo, F. Q.; Cezar, M. F.; Gonzaga Neto, S.; Cunha, M. G. G. and Santos, N. M. 2008. Desempenho e características de carcaça de cordeiros terminados em confinamento com diferentes condições corporais. Revista Brasileira de Saúde e Produção Animal 9:795-803.

Tonetto, C. J.; Pires, C. C.; Müller, L.; Da Rocha, M. G.; Da Silva, J. H. S.; Cardoso, A. R. and Peres Neto, D. 2004. Ganho de peso e características da carcaça de cordeiros terminados em pastagem natural suplementada, pastagem cultivada de azevém (Lolium multiflorum Lam.) e confinamento. Revista Brasileira de Zootecnia 33:225-233.

Valadares Filho, S. C.; Machado, P. A. S.; Chizzotti, M. L.; Amaral, H. F.; Magalhães, K. A.; Rocha Junior, V. R. and Capelle, E. R. 2010. Tabelas brasileiras de composição de alimentos para bovinos. 3 ed. UFV/DZO, Viçosa, MG.

Vieira, M. M. M.; Cândido, M. J. D.; Bomfim, M. A. D.; Severino, L. S.; Zapata, J. F. F.; Beserra, L. T.; Meneses, A. J. G. and Fernandes, J. P. B. 2010. Características da carcaça e dos componentes não-carcaça em ovinos alimentados com rações à base de farelo de mamona. Revista Brasileira de Saúde e Produção Animal 11:140-149. 